\title{
Teachers' perspectives on project-based learning in mathematics and science
}

\author{
Elina Viro ${ }^{1}$, Daranee Lehtonen ${ }^{2}$, Jorma Joutsenlahti ${ }^{2}$ and Ville Tahvanainen ${ }^{3}$ \\ ${ }^{1}$ Faculty of Information Technology and Communication Sciences, Tampere University, Tampere, Finland \\ ${ }^{2}$ Faculty of Education and Culture, Tampere University, Tampere, Finland \\ ${ }^{3}$ Philosophical Faculty, University of Eastern Finland, Joensuu, Finland \\ For correspondence: elina.viro@tuni.fi
}

\begin{abstract}
:
In order to thrive in today's uncertain environment, there is a need to master 21st century skills as well as knowledge of key subjects. Project-based learning (PBL) has been recommended as an important instructional strategy to prepare students for their future work and life. As teachers play an important role in classroom instructional practice, understanding their perspectives on PBL is essential in order to provide them with support for its successful implementation. We investigated how Finnish pre- and in-service class teachers and mathematics and science teachers $(N=257)$ view PBL in terms of (1) its objectives, (2) its characteristics, (3) the suitable application and situation regarding its implementation, and (4) support for and barriers to its implementation. We collected data from two questionnaire surveys, project plans, and reports and then analysed them quantitatively. We found that a majority of the teachers considered the development of students' knowledge and understanding of mathematics and science, and 21st century skills as important objectives of PBL in mathematics and science education. The development of teamwork skills and the connection between theory and practice were regarded as key PBL characteristics. Moreover, PBL was perceived as suitable for both revising and learning new content. Nevertheless, the relative inadequacy of resources and support for PBL implementation was reported. Of particular necessity were ready-made project instructions, ideas, tips, and examples; advice from experienced teachers; training and guidance on basic PBL issues; and more time allocation. We discuss implications for teachers' professional development towards PBL.
\end{abstract}

Keywords: project-based learning, mathematics and science education, 21st century skills, mathematical proficiency, science proficiency, curriculum

\section{Introduction}

The contemporary period is characterised by constant economic, societal, and technological change, challenging the manner in which our education system prepares students for further education, careers, citizenship, and life. Thus, mastery of key subjects, such as reading, writing, mathematics, and science, is not enough to succeed in work and life in the 21st century. A new set of skills, including critical thinking, problem solving, communication, collaboration, creativity, innovation, and leadership, is also required (e.g., Markham et al., 2006; Partnership for 21st Century Skills [P21], 2007; World Economic Forum [WEF], 2018). Recently, several national curricula, including that of Finland (Finnish National Agency for Education [EDUFI], 2016a, 2016b), have responded to these future challenges by encouraging teachers to implement project-based learning (PBL), among other instructional strategies, in their classrooms in order to develop students' 21st century skills. PBL, which involves learning based around projects driven by a realistic problem (Krajcik \& Blumenfeld, 2006; Markham et al., 2006; Thomas, 2000) and was introduced at the beginning of the 20th century, not only promotes students' knowledge of key subjects but also the skills needed for the 21st century (e.g., Han et al., 2015; Kay \& Greenhill, 2011; Larmer et al., 2015). 
In response to these educational reforms, teachers are mostly required to implement PBL on their own, without any guidance or support (Thomas, 2000), and have to confront various challenges to do so (Han et al., 2015; Larmer et al., 2015). Research has indicated that teachers play an important role in the successful implementation of PBL (Han et al., 2015; Kokotsaki et al., 2016; Larmer et al., 2015). Thus, understanding how teachers view PBL is essential for providing them with the necessary support (e.g., training, resources, and administrations) for its successful implementation in their classrooms. This study investigates how Finnish pre- and in-service class teachers and mathematics and science teachers view PBL in terms of (1) its objectives, (2) its characteristics, (3) suitable application and situation regarding its implementation, and (4) support for and barriers to its implementation.

\section{Theoretical background}

21st century skills.

There have been recent debates regarding what the future of work might look like and the implications for present and future workforces. To address these problems, the WEF (2018) conducted the Future of Jobs Survey, which covers wide-ranging industries and geographies. Their findings indicated that by 2022, machines and algorithms will increasingly complement human skills in data processing and information searching and will supplement physical and manual work tasks, while humans will perform high-value tasks that require, for instance, communicating, developing, reasoning, and decision making. Consequently, there will be a significant shift in the skills needed to perform most jobs (WEF, 2018). Skills demand trends (WEF, 2018) show that by 2022, there will be a decline in the demand for skills, including physical abilities and manual, reading, writing, math, and active listening skills, and that the demand for skills such as analytical and critical thinking, reasoning, innovation, creativity, problem solving, and leadership will either increase or remain constant.

One therefore needs to master various skills in order to thrive in this uncertain environment in addition to acquiring knowledge of key subjects, such as reading, writing, mathematics, and science (Kay \& Greenhill, 2011; P21, 2007). Various essential skills for 21st century work and life have been proposed under several names, including 21st century skills, soft skills, interdisciplinary skills, and success skills (Larmer et al., 2015). In this study, we use the term 21st century skills. To prepare future workforces, policymakers and educators will need to align curricula, education, and training systems with 21st century skills (Kay \& Greenhill, 2011; P21, 2007; WEF, 2018).

P21 (2007), a leading advocacy organisation working to infuse 21st century skills into education, developed the Framework for 21st Century Learning, which can be used to prepare children for their future work and life. According to P21 (2007), children must have knowledge of key subjects, such as reading, writing, mathematics, and science, as well as an understanding of academic content in relation to 21st century interdisciplinary themes, such as global awareness and civic literacy. Moreover, they must master three sets of skills: learning and innovation skills; information, media, and technology skills; and life and career skills (P21, 2007):

- Learning and innovation skills consist of creativity and innovation, critical thinking and problem solving, and communication and collaboration. These skills can distinguish those who are prepared for the modern world from those who are not.

- Information, media, and information and communications technology (ICT) literacies are more important than ever, as we have access to large quantities of information and can freely make our own contributions through different media within a fast-changing technology environment.

- Life and career skills are necessary for citizens of the 21st century. For example, they need to be adaptable to diverse and changing environments, be able to work independently, be 
accountable for their own actions, show leadership, be responsible to others, and have social and cross-cultural skills.

To prepare students for their future work and life, P21 (2007) calls for the integration of 21st century skills and curricula into the teaching and learning of all school subjects. Students must learn to apply and develop their 21st century skills while learning school subjects, such as mathematics, through project-based or other applied work.

In response to economic, societal, and technological changes, the aim of the Finnish National Core Curriculum for Basic Education 2014 (EDUFI, 2016a) and the National Core Curriculum for General Upper Secondary Schools 2015 (EDUFI, 2016b) has been to enable students to develop various skills for working and living in the 21st century. The curriculum for basic education (EDUFI, 2016a) introduced transversal competences - comprising knowledge, skills, values, attitudes, and will - which cross the boundaries of school subjects and link various kinds of skills-related knowledge as its mission and general goals. Basic education must enable students to develop competences, such as thinking and learning to learn, multiliteracy, ICT competence, and working life competence and entrepreneurship. Likewise, the curriculum for upper secondary schools (EDUFI, 2016b) introduced cross-curricular themes - transversal competences that cross the boundaries of school subjects - as part of its learning objectives and core educational contents. Through cross-curricular themes (e.g., active citizenship, entrepreneurship, and the world of work; multiliteracy and the media; and technology and society), upper secondary students can develop the knowledge and skills needed for the modern world. All in all, transversal competences (EDUFI, 2016a) and cross-curricular themes (EDUFI, 2016b) are aligned with the P21's (2007) Framework for 21st Century Learning.

Proficiency in mathematics and science.

Twenty-first century skills are not completely separate from individual subjects. Problem solving, for example, is closely linked to mathematics (Common Core State Standards Initiative, n.d.), and inquiries that involve collaborating with other students are an essential part of science education (Larmer et al., 2015). However, 21st century skills alone are not enough; students need to understand the content of key subjects, in this case, mathematics and science knowledge.

Kilpatrick et al. (2001) defined mathematical proficiency using five strands that interact with one another: conceptual understanding, procedural fluency, strategic competence, adaptive reasoning, and productive disposition. Moschkovich (2015) broadened this five-strand model to describe academic literacy in mathematics. A description of each strand, based on the model by Kilpatrick et al. (2001), is as follows:

- Conceptual understanding is comprehension of mathematical concepts, operations, and relations. It is more than just the knowledge of facts or methods; it is also the ability to use mathematical concepts in the right context and to connect new concepts to those learned earlier.

- Procedural fluency involves flexible, efficient, accurate, and appropriate calculation. This strand has a close connection to conceptual understanding because it is not possible to understand a mathematical concept without managing the procedures behind it.

- Strategic competence or problem solving is the ability to formulate a problem into a mathematical form in order to solve it. It is proficiency in applying learned concepts and procedures to a new context.

- Adaptive reasoning refers to logical thinking, reflection, and explanation of one's own solution. It is the ability to justify the choice of solution and/or procedures.

- Productive disposition is the ability to see the importance of mathematics and to understand its usability in real life. Joutsenlahti (2005) used the term view of mathematics to broaden the 
concept of productive disposition to students' beliefs and attitudes regarding mathematics and mathematics learning.

According to the Organization for Economic Co-Operation and Development (OECD)'s Programme for International Student Assessment (PISA) 2018 (2019), scientific literacy requires three key competencies: the ability to explain phenomena scientifically, to evaluate and design scientific enquiry, and to interpret data and evidence scientifically. The ability to explain phenomena scientifically requires particular content knowledge (i.e., students' understanding of scientific facts and theories). The two other competences require procedural and epistemic knowledge (i.e., students' understanding of how ideas are produced and their underlying rationale). Correspondingly, the U.S. National Research Council (2012) used three major elements to describe the proficiencies for K-12 science education: disciplinary core ideas, scientific and engineering practices, and cross-cutting concepts. Disciplinary core ideas consist of learning objectives linked to a certain discipline. Scientific and engineering practices (e.g., analysing and interpreting data or engaging in an argument derived from evidence) resemble the key competences of scientific literacy defined by PISA 2018 (OECD, 2019). Examples of cross-cutting concepts are cause and effect or energy and matter. Common among both definitions of science proficiency is the role of multidisciplinary skills.

\section{Project-based learning.}

Scholars (e.g., Capraro \& Slough, 2008; Krajcik \& Blumenfeld, 2006; Markham et al., 2006) have defined PBL somewhat differently. However, while their definitions use different words, they usually describe the same things (Erdogan \& Bozeman, 2015). Capraro and Slough (2008) defined Science, Technology, Engineering, and Mathematics (STEM) PBL as 'An ill-defined task with a well-defined outcome situated within a contextually rich task requiring students to solve several problems, which when considered in their entirety, showcase student mastery of several concepts of various STEM subjects' (p. 4).

Larmer et al. (2015) argued that the objective of PBL is to assist students in developing not only their knowledge and understanding of subjects but also success skills (i.e., 21st century skills). They emphasised that during the project, students are required to apply their knowledge of subjects to practice. As a result, students promote their deep learning of subjects through understanding and the use of several skills, such as critical thinking, problem solving, collaboration, and self-management. Similarly, Capraro and Slough (2008) emphasised that besides the anticipated learning outcomes, PBL normally leads to additional outcomes, including thinking skills, collaboration, communication, and problem solving. Aruga et al. (as cited in Ozaki et al., 2017) also noted an increase in students' selfmotivation and empowerment as a PBL objective.

Scholars (Kokotsaki et al., 2016; Krajcik \& Blumenfeld, 2006; Larmer et al., 2015; Thomas, 2000) have defined similar essential characteristics that comprise PBL and distinguish it from other instructional approaches. Using real-world questions and problems, PBL encourages students to develop their conceptual knowledge of subjects and connect this knowledge with its application. Students are driven to carry out projects through inquiry-based and constructive investigation. PBL is a studentcentred learning process in which students are empowered and actively involved. Other characteristics of PBL include collaboration and interaction with others (Alozie et al., 2010; Kokotsaki et al., 2016), use of technology tools to support learning (Krajcik \& Blumenfeld, 2006), reflection on the problem-solving strategies used and on project outcomes (Larmer et al., 2015), creation of project outputs such as artefacts (Alozie et al., 2010; Krajcik \& Blumenfeld, 2006), and sharing products with the public (Larmer et al., 2015).

Previous studies have identified various factors that facilitate PBL implementation. Teachers' skills and ability to guide students play a key role in the success of PBL (Kokatsaki et al., 2016; Tal et al., 
2006). Additionally, students' teamwork (Kokatsaki et al., 2016) and communicative competences (Campbell, 2012) are crucial for collaboration in PBL. Students' activities and a positive atmosphere also contribute to successful PBL (Habók \& Nagy, 2016). Moreover, support from the school and other teachers (Kokatsaki et al., 2016) as well as available materials (Tal et al., 2006) are important for its implementation. While modern digital technology enables students to design and develop their projects (Kokatsaki et al., 2016), its use is not considered important in PBL (Habók \& Nagy, 2016).

A body of research has reported on different barriers to the implementation of PBL, such as inadequacies in relation to teachers' understanding, skills, and ability to implement PBL as well as their resistance to student-centred instruction (Marx et al., 1997; Mentzer et al., 2017). Another barrier involves the lack of resources, particularly time (Aksela \& Haatainen, 2019; Marx et al., 1997) and challenges regarding scheduling (Viro \& Joutsenlahti, 2018; Viro et al., 2016). Other barriers concern students' motivation (Blumenfeld et al., 1991), knowledge, and skills (Aksela \& Haatainen, 2019), especially 21st century skills (Viro \& Joutsenlahti, 2018), as well as technological problems, such as a lack of competence relating to information technology skills (Marx et al., 1997), slow wireless Internet connection, and lack of computer hardware and software (Viro et al., 2016).

Researchers have recommended providing students and teachers with support in order to successfully implement PBL in schools. Students should be guided through time and selfmanagement as well as supported with technological resources (Kokatsaki et al., 2016). Correspondingly, schools should provide teachers with professional development opportunities and networking support (Kokatsaki et al., 2016). Based on the findings of Han et al. (2015), teachers' understanding of the requirements for successful PBL plays a vital role in how they implement PBL in their class. This, in turn, directly goes hand in hand with students' learning outcomes. Some Finnish universities (e.g., University of Helsinki and University of Jyväskylä) have incorporated PBL in their pre-service class teacher and subject teacher trainings. Different PBL continuing courses and support, especially for in-service STEM teachers, are also available (Viro \& Joutsenlahti, 2018).

The literature addresses several issues relating to PBL, such as definitions, objectives, characteristics, challenges, and support. Nevertheless, there is a dearth of research on the suitable application and situation of PBL implementation.

\section{Methods}

\section{Context of the study.}

The purpose of this study was to investigate Finnish class teachers' and subject teachers' views on PBL in mathematics and science education. This particular setting was chosen as the study context because the new curricula for basic education (EDUFI, 2016a) and upper secondary schools (EDUFI, 2016b) recommend PBL among other instructional strategies. Nevertheless, Finnish teachers have autonomy regarding how they teach. In Finland, qualified class and subject teachers are required to complete a master's degree, pedagogical studies, and either multidisciplinary studies in the subjects taught in basic education (in the case of class teachers) or studies in any subject taught in schools (in the case of subject teachers). Class teachers provide instruction for all school subjects in primary school (Grades 1-6), whereas subject teachers provide instruction for a specific subject taught in lower (Grades 7-9) and upper secondary schools.

\section{Participants and data collection.}

We gathered data from two separate questionnaire surveys: PBL in mathematics (Survey A) and PBL in mathematics and sciences (Survey B). Both questionnaires were comprised of open-ended items to gather the participants' rationale and comments as well as Likert-type items to determine the degree of their responses regarding the survey items. While Survey A only focused on PBL in one specific 
study subject (mathematics), Survey B not only focused on PBL in mathematics and sciences but also on how it could be used in multidisciplinary studies. We also collected data from seven teachers' project plans and reports on PBL in mathematics. All participants gave permission to use their questionnaire responses, project plans, and project reports. Moreover, their personal data were processed according to the EU General Data Protection Regulation (GDPR). Figure 1 presents the research participants' classifications according to the surveys in which they participated and their previous experiences with PBL implementation.

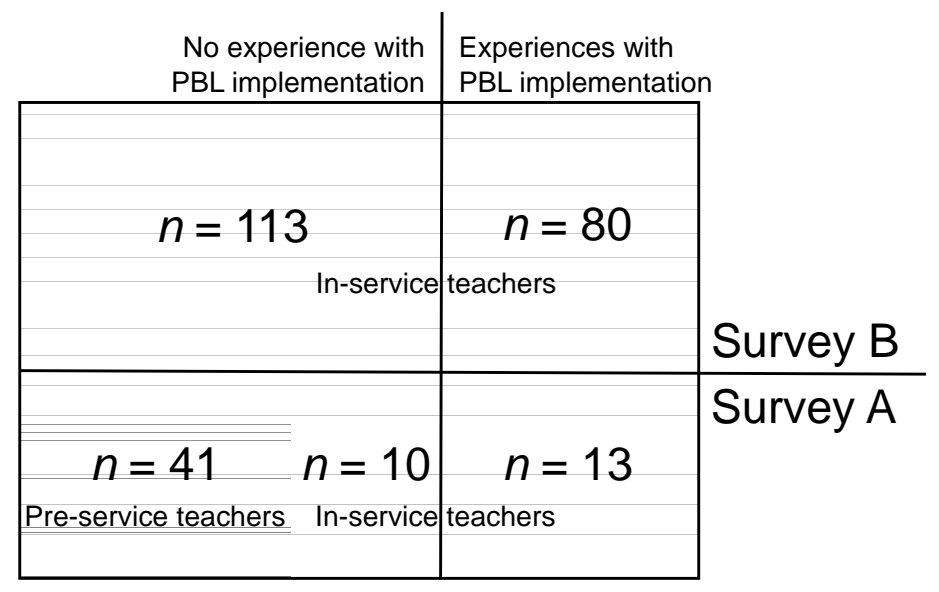

Figure 1. Participants $(N=257)$ for both surveys based on their experiences with PBL implementation

Survey A.

This survey was conducted in two parts in the autumn of 2018: one for in-service teachers and another for pre-service teachers. The items in both surveys were almost identical. Some items were edited so that they were relevant to the context of the participants. The questionnaires were composed of the participants' background and views on PBL in terms of its objectives, characteristics, suitable application and situation, and factors that support or hinder its implementation.

The first part of Survey A targeted 40 Finnish in-service teachers participating in either an online or multiform course on mathematical PBL. The participants of the online course worked in primary or lower secondary schools throughout Finland, whereas those of the multiform course were from a couple of small municipalities near the location where the training was organised. All participants were asked to complete the questionnaire before the course started. In total, we received 23 responses (years of teaching experience: $M=12.4, S D=6.7$ ): 10 from primary school class teachers and 13 from lower secondary school mathematics teachers. As part of one of the courses, the participants were required to plan PBL for their mathematics class, implement their plan, and then report on their implementation. Seven teachers returned their project plans and reports, which were also included in this study.

The second part of Survey A targeted about 100 pre-service teachers participating in class teacher or mathematics teacher programmes at Tampere University. The survey was a voluntary part of their courses. We received 41 responses: 29 from pre-service class teachers and 12 from pre-service mathematics teachers.

Survey $B$.

This survey consisting of 44 items was part of one of our development projects. However, in this study, we only used four items that were of relevance to our research objectives, as they were concerned with perceptions of the learning objectives, characteristics, and necessary support for PBL (see Table 1). In the autumn of 2018, the survey was randomly sent to 53 municipalities in Finland representing three different levels of population density - highly populated, densely populated, and 
rarely populated - according to the categorisation of the Ministry of Education and the Finnish National Agency for Education (Kumpulainen, 2017). The chosen municipalities were asked to deliver an email with a survey link to 982 primary school class teachers and secondary school mathematics or science teachers working in 140 schools. We received survey responses from 193 teachers (years of teaching experience: $M=15.7, S D=10.0$ ): 77 class teachers, 91 subject teachers, and 25 teachers qualified as class and subject teachers from 78 schools in 41 municipalities.

Table 1. The research objectives and questionnaire items from both surveys

\begin{tabular}{|c|c|c|}
\hline Research Objectives & Items in Survey A & Items in Survey B \\
\hline 1. Objectives of PBL & $\begin{array}{l}\text { A1: List, in order of importance, } \\
\text { the five most important } \\
\text { objectives of mathematical PBL. } \\
\text { (open-ended) }\end{array}$ & $\begin{array}{l}\text { B1: What is the most important } \\
\text { objective of PBL? } \\
\text { (open-ended) }\end{array}$ \\
\hline $\begin{array}{l}\text { 2. Characteristics of } \\
\text { PBL }\end{array}$ & $\begin{array}{l}\text { A2.1: List, in order of } \\
\text { importance, the three } \\
\text { characteristics that best describe } \\
\text { successful mathematical PBL. } \\
\text { (open-ended) } \\
\text { A2.2: List, in order of } \\
\text { importance, the three } \\
\text { characteristics of PBL that } \\
\text { threaten its success in } \\
\text { mathematics. } \\
\text { (open-ended) }\end{array}$ & $\begin{array}{l}\text { B2: The characteristics of PBL are: } \\
\text { - Development of teamwork } \\
\text { skills } \\
\text { - Development of problem- } \\
\text { solving skills } \\
\text { - Self-assessment } \\
\text { - Etc. } \\
\text { (Five-level Likert-type item rated } \\
\text { from 1: strongly disagree to 5: } \\
\text { strongly agree) }\end{array}$ \\
\hline \multirow[t]{2}{*}{$\begin{array}{l}\text { 3. Suitable } \\
\text { application and } \\
\text { situation regarding } \\
\text { implementation of } \\
\text { PBL }\end{array}$} & $\begin{array}{l}\text { A3.1: } \\
\text { - PBL is not suitable for } \\
\text { mathematics education. } \\
\text { - PBL is suitable for revising } \\
\text { mathematics contents. } \\
\text { - PBL is suitable for learning } \\
\text { new content. } \\
\text { - PBL can only be used for less } \\
\text { important things. } \\
\text { - Mathematics is a supportive } \\
\text { tool for projects in other } \\
\text { study subjects. } \\
\text { (Four-level Likert-type item } \\
\text { rated from 1: strongly disagree to } \\
\text { 4: strongly agree) }\end{array}$ & - \\
\hline & $\begin{array}{l}\text { A3.2: What is the most suitable } \\
\text { situation for implementing PBL } \\
\text { in mathematics? Why? } \\
\text { (open-ended) }\end{array}$ & - \\
\hline $\begin{array}{l}\text { 4. Support for and } \\
\text { barriers to the } \\
\text { implementation of } \\
\text { PBL }\end{array}$ & $\begin{array}{l}\text { A4.1: What factors support PBL } \\
\text { in mathematics at your } \\
\text { school?/What factors do you } \\
\text { believe can support PBL in } \\
\text { mathematics? } \\
\text { (open-ended) }\end{array}$ & $\begin{array}{l}\text { B4.1: Your school has provided } \\
\text { enough time and material } \\
\text { resources for integrative learning } \\
\text { modules through PBL. } \\
\text { (Five-level Likert-type item rated } \\
\text { from 1: strongly disagree to 5: } \\
\text { strongly agree) }\end{array}$ \\
\hline
\end{tabular}




\section{A4.2: What hinders PBL in \\ mathematics at your school?/What do you believe \\ hinders PBL in mathematics? \\ (open-ended)}

A4.3: What kinds of support do you need in order to implement PBL in mathematics?

(open-ended)
B4.2: What kinds of support do you need in order to implement PBL? (open-ended)

Note: All items were translated from Finnish to English.

Data analysis.

Two separate and somewhat different questionnaires were used for Surveys A and B. The original items used in this study are presented in Table 1. We compared the data from Surveys A and B that corresponded to the same topics (Research Objectives 1-4) of our study. Qualitative content analyses and quantitative methods were used to analyse the dataset. Different groups of participants (i.e., preand in-service teachers as well as class and subject teachers) were treated equally in all analyses.

Coding.

First, all responses to each open-ended item were analysed and then categorised into sub-themes, which were grouped into themes. The analysis used data-driven open coding. The only exception was the analysis of the responses regarding the objectives of PBL (Items A1 and B1), which was partly guided by the literature. The objectives (i.e., themes) concerning the development of mathematical competence and 21st century skills were a priori codes deriving from the literature, while those concerning multidisciplinarity and a working method that differed from the traditional instruction were open coded (see Tables 2 and 3). Table 5 is an example of open coding. It displays the coding themes for positive and negative characteristics of PBL in mathematics with the sub-themes in parentheses. For the Likert-type responses to Item B2 on the characteristics of PBL, only the responses of strongly agree were included in our study. The inclusive responses were treated as they would be the participants' open responses and coded under each provided claim (i.e., theme). At the beginning of the coding process, two authors discussed and reached a joint decision on how to classify the openresponse data. Then, one author was responsible for categorising the data while the other crosschecked the data for doubtful circumstances. If there was still disagreement, a discussion took place to reach a consensus.

\section{Quantitative analysis.}

Finally, all the data (i.e., the open coded and Likert-type responses) were analysed quantitatively in terms of frequencies and percentages using the Statistical Package for the Social Sciences (SPSS) software (IBM, Armonk, NY). Then, the results were compared between different groups of participants. Pearson's chi-squared test was used to investigate the statistical significance of the findings. However, due to the limited number of survey participants, it was not possible to examine the statistical significance of all comparisons. Thus, Pearson's chi-squared test statements are presented in the results section only when it was possible to conduct this test.

\section{Results and Discussion}

Objectives of PBL.

The objectives regarding the implementation of PBL play a crucial role both in the implementation and success of the project. Thus, we examined how the teacher participants prioritised the PBL objectives. Table 2 presents the results of Survey A relating to the five most important objectives of mathematical PBL (Item A1) based on the participants' $(n=64)$ opinions in relation to mathematics, 
21st century skills, multidisciplinarity, and working methods. Most participants considered the development of mathematical competence to be one of the most important objectives. Their responses referred to mathematical proficiency, as per Kilpatrick et al. (2001), especially adaptive reasoning $(22 \%)$ and view of mathematics $(50 \%)$, and some referred to mathematics learning in general $(52 \%$ based on short responses). Numerous participants also regarded the development of 21st century skills as one of the most important objectives. Developing learning and innovation skills $(77 \%)$, especially communication and collaboration skills, was highly regarded as a key objective, followed by the development of life and career skills (25\%). Some participants also considered the development of multidisciplinarity $(16 \%)$ and offering a working method that differed from traditional instruction $(19 \%)$ as important objectives. We also conducted a separate investigation of the responses listing the most important objective of mathematical PBL (see $f$ [main] and \% [main] in Table 2). The findings support the responses regarding the five most important objectives.

Table 2. Survey A on teachers' opinions of important objectives of mathematical PBL

\begin{tabular}{|c|c|c|c|c|c|}
\hline \multicolumn{2}{|c|}{ Objectives of PBL } & \multirow{2}{*}{$\begin{array}{c}f \text { (main) } \\
2\end{array}$} & \multirow{2}{*}{$\begin{array}{c}\% \text { (main) } \\
3.1\end{array}$} & \multirow{2}{*}{$\begin{array}{c}f(\text { all }) \\
2\end{array}$} & \multirow{2}{*}{$\begin{array}{c}\% \text { (all) } \\
3.1\end{array}$} \\
\hline Mathematics & Conceptual understanding & & & & \\
\hline & Strategic competence & 3 & 4.7 & 9 & 14.1 \\
\hline & Adaptive reasoning & 6 & 9.4 & 14 & 21.9 \\
\hline & View of mathematics & 14 & 21.9 & 32 & 50.0 \\
\hline & Procedural fluency & 0 & 0.0 & 3 & 4.7 \\
\hline & Mathematics learning in general & 15 & 23.4 & 33 & 51.6 \\
\hline \multirow[t]{3}{*}{$\begin{array}{l}\text { 21st century } \\
\text { skills }\end{array}$} & $\begin{array}{l}\text { Learning and innovation skills } \\
\text { (creativity, critical thinking and } \\
\text { problem-solving, and communication } \\
\text { and collaboration) }\end{array}$ & 20 & 31.3 & 49 & 76.6 \\
\hline & $\begin{array}{l}\text { Information, media, and technology } \\
\text { skills } \\
\text { (information and ICT literacy) }\end{array}$ & 0 & 0.0 & 2 & 3.1 \\
\hline & $\begin{array}{l}\text { Life and career skills } \\
\text { (flexibility and adaptability, initiative } \\
\text { and self-direction, productivity and } \\
\text { accountability, and leadership and } \\
\text { responsibility) }\end{array}$ & 1 & 1.6 & 16 & 25.0 \\
\hline \multicolumn{2}{|c|}{$\begin{array}{l}\text { Multidisciplinarity } \\
\text { (overall picture in terms of conceptualising and } \\
\text { perceiving, different perspectives, and cause-and-effect } \\
\text { understanding) }\end{array}$} & 2 & 3.1 & 10 & 15.6 \\
\hline \multicolumn{2}{|c|}{$\begin{array}{l}\text { A working method that differs from the traditional } \\
\text { instruction } \\
\text { (action-based, versatile, diverse, learner-centred, } \\
\text { experiential, phenomenon-based, observation-based, and } \\
\text { new teaching and learning tools) }\end{array}$} & 1 & 1.6 & 12 & 18.8 \\
\hline
\end{tabular}

Note: Objectives listed as the most important are displayed in the $f$ (main) column. All listed objectives were counted together and are displayed in the $f$ (all) column. The percentage of each objective was calculated in relation to the number of participants $(n=64$; non-respondents $=0)$. For precise descriptions of conceptual understanding, strategic competence, adaptive reasoning, view of mathematics, and procedural fluency, see the subsection on proficiency in mathematics and science in the theoretical background section. 
To better understand how the different groups of participants viewed the two most important objectives of mathematical PBL (i.e., the development of mathematical competence and 21st century skills), we investigated the frequency of these objectives listed in the first order as the most important. The difference between class teachers' and mathematics teachers' opinions was statically significant ( $p$ $<0.001)$. Nearly all the mathematics teachers $(92 \%)$ prioritised the development of mathematical competence, while less than half of the class teachers (44\%) shared this opinion. In contrast, $49 \%$ of the class teachers prioritised the development of 21 st century skills compared to only $8 \%$ of the mathematics teachers. The dissimilarity between the pre- and in-service teachers' perspectives was also statistically significant $(p=0.016)$. The majority of the in-service teachers $(78 \%)$ prioritised the development of mathematical proficiency, whereas about half of the pre-service teachers $(54 \%)$ shared this opinion. Conversely, $44 \%$ of the pre-service teachers highlighted 21 st century skills as the most important objective, with only $13 \%$ of the in-service teachers concurring.

In the project plans and reports, which were part of the mathematical PBL course, seven in-service teachers (three class teachers and four subject teachers) reported the objectives of PBL implementation in their mathematics class in a manner that was similar to the results of Survey A (see Table 3). The development of mathematical competence and 21st century skills were considered the two most important PBL objectives.

Table 3. Frequency of objectives of mathematical PBL in teachers' project plans and reports

\begin{tabular}{|c|c|c|c|}
\hline \multicolumn{2}{|r|}{ Objectives of PBL } & \multirow{2}{*}{$\frac{f}{4}$} & \multirow{2}{*}{$\begin{array}{l}\text { Examples of Teachers' Descriptions of the } \\
\text { PBL Objectives } \\
\text { 'To reinforce understanding of basic geometric } \\
\text { concepts' }\end{array}$} \\
\hline Mathematics & Conceptual understanding & & \\
\hline & Strategic competence & 3 & $\begin{array}{l}\text { 'To guide students to develop their skills } \\
\text { regarding how to raise questions' }\end{array}$ \\
\hline & Adaptive reasoning & 2 & $\begin{array}{l}\text { 'To guide students to develop their skills } \\
\text { regarding how to draw a conclusion based on } \\
\text { their own observation' }\end{array}$ \\
\hline & View of mathematics & 4 & $\begin{array}{l}\text { 'The objective is to get students to understand } \\
\text { the historical and present importance of } \\
\text { encrypted writing' }\end{array}$ \\
\hline & Procedural fluency & 3 & $\begin{array}{l}\text { 'Setting up our classroom's shop where } \\
\text { students can play shopping and selling } \\
\text { (calculate shopping price, compare prices, and } \\
\text { practice multiplication table)' }\end{array}$ \\
\hline \multirow[t]{3}{*}{$\begin{array}{l}\text { 21st century } \\
\text { skills }\end{array}$} & $\begin{array}{l}\text { Learning and innovation } \\
\text { skills }\end{array}$ & 3 & 'Learn how to work in pairs/groups' \\
\hline & $\begin{array}{l}\text { Information, media, and } \\
\text { technology skills }\end{array}$ & 3 & 'To be familiar with how to use GeoGebra*' \\
\hline & Life and career skills & 0 & - \\
\hline \multicolumn{2}{|c|}{ Multidisciplinarity } & 3 & $\begin{array}{l}\text { 'Design, ideation, and presentation of } \\
\text { multidisciplinarity, such as mother tongue } \\
\text { skills and transversal competences' }\end{array}$ \\
\hline \multicolumn{2}{|c|}{$\begin{array}{l}\text { Working method } \\
\text { that differs from } \\
\text { traditional instruction }\end{array}$} & 2 & $\begin{array}{l}\text { 'To use diverse ways of working, among other } \\
\text { things, and to learn through an action-based } \\
\text { approach' }\end{array}$ \\
\hline
\end{tabular}

Note: $n=7$. The description of each objective of mathematical PBL is the same as in Table 2. Each objective was counted once per participant. *GeoGebra is an interactive geometry, algebra, statistics, and calculus application. 
Based on the results of Survey B, Table 4 shows that the most important objective of PBL (Item B1), according to the participants $(n=193)$, was also related to the study subjects (i.e., mathematics and sciences), 21st century skills, multidisciplinarity, and working methods. For $39 \%$ of the participants, the development of 21 st century skills, particularly learning and innovation skills (26\%), was regarded as the most important objective. Some participants (31\%) also considered the development of study subject competence to be the most important objective. Of these, $18 \%$ emphasised the view of the study subject (i.e., beliefs and attitudes regarding the study subject and its learning), especially motivation, connection between practice and theory, success, and relevance. Nevertheless, the differences between the groups' (e.g., class teachers vs. subject teachers, teaching experience, or PBL implementation experience) responses regarding the most important objective were not statistically significant.

Table 4. Survey B on teachers' opinions of the objectives of PBL

\begin{tabular}{llcc}
\hline Objectives of PBL & & $f$ & $\mathbf{\%}$ \\
\hline Study subjects & The learning of concepts & 1 & 0.5 \\
(i.e., mathematics and & Application in new situations & 5 & 2.6 \\
science) & Thinking and understanding & 9 & 4.7 \\
& View of the study subjects & 34 & 17.6 \\
& Learning of study subjects in general & 10 & 5.2 \\
21st century skills & Learning and innovation skills & 51 & 26.4 \\
& Information and media skills & 8 & 4.1 \\
Multidisciplinarity & Life and career skills & 17 & 8.8 \\
$\begin{array}{l}\text { Working method that differs } \\
\text { from traditional instruction }\end{array}$ & & 28 & 14.5 \\
\hline
\end{tabular}

Note: The description of each objective concerning 21st century skills, multidisciplinarity, and working methods is the same as in Table 2. Some participants listed more than one objective as the most important, and these were also included in the data. The percentage of each objective was calculated in relation to the number of participants $(n=193$; non-respondents $=18)$.

We cross-tabulated the responses from the two surveys. Figure 2 shows that different types of objectives were emphasised relatively equally in Survey B but not in Survey A. The most emphasised objective in Survey A was the development of mathematics (89\%), whereas in Survey B, it was the development of multidisciplinarity (34\%). In both surveys, the second most emphasised objective was the development of 21st century skills (88\% in Survey A and 33\% in Survey B). However, the third most emphasised objective in Survey A was providing a working method that differed from the traditional instruction (19\%), while in Survey B, it was the development of mathematics or science $(29 \%)$. 


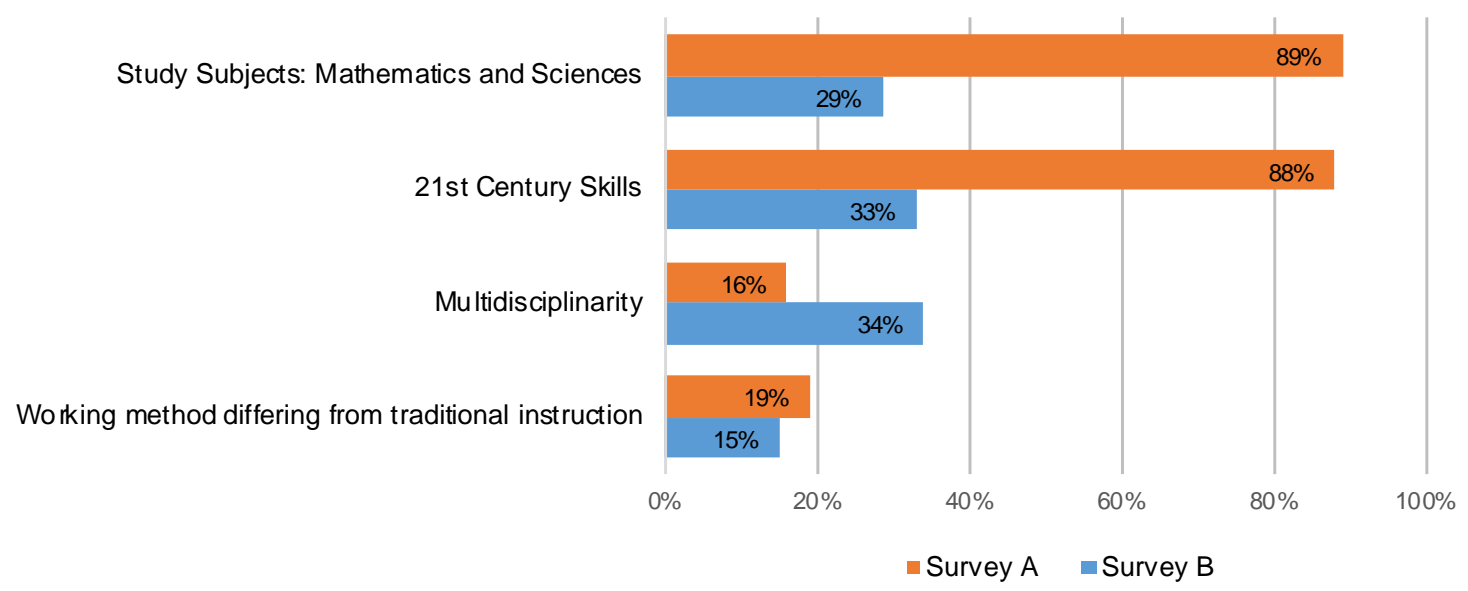

Figure 2. Teachers' opinions of important PBL objectives by survey

Note: Survey A: $n=64$; non-respondents $=0$. Survey B: $n=193$; non-respondents $=18$. All responses of each participant that belonged to the same theme were counted once. The percentage of the responses was calculated in relation to the number of participants in each survey.

In Tables 2 and 4, each participant's responses were categorised into themes of four types of objective (i.e., study subjects, 21st century skills, multidisciplinarity, and a working method that differs from traditional instruction) and were counted separately to investigate their responses in detail. However, in Figure 2, each participant's responses belonging to the same type of objective were grouped together and counted as one for the purpose of comparing the responses from both surveys. While a great number of Survey A participants listed three to five important objectives, the majority of Survey B participants listed only one. Thus, their varied responses to the surveys should be taken into consideration when interpreting Figure 2.

The findings from both surveys strongly confirmed the assertion of Larmer et al. (2015) that the development of knowledge and understanding of study subjects, and expansion of 21st century skills are regarded as important objectives of PBL implementation. Besides learning in general, Survey A participants' responses to students' development of mathematics could be categorised according to Kilpatrick et al.'s (2001) mathematical proficiency. Interestingly, Survey B participants' responses to students' development of mathematics and science could be similarly classified. Moreover, the participants' emphasis on the development of 21st century skills is also in line with the aim of Finland's curricula for basic education (EDUFI, 2016a) and upper secondary schools (EDUFI, 2016b) in terms of student development.

In both surveys, the objectives that participants perceived as important included the development of multidisciplinarity, support for the understanding of academic content through 21st century interdisciplinary themes (P21, 2007), cross-curricular themes in the Finnish National Core Curriculum for General Upper Secondary Schools 2015 (EDUFI, 2016b), and the cross-cutting concepts of proficiency in K-12 science education recommended by the U.S. National Research Council (2012). In addition to the PBL objectives described in the literature, this study found a new PBL objective: offering a working method that differed from traditional instruction.

\section{Characteristics of PBL.}

We also investigated the participants' responses regarding the characteristics of PBL. Based on the participants' $(n=64)$ responses, Table 5 presents the results of Survey A for three characteristics that were listed as best describing successful mathematical PBL (Item A2.1) and three that threaten its success in mathematics (Item A2.2). Based on the participants' opinions, the same issues could be seen as either positive or negative characteristics of PBL depending on their effect on it. PBL was perceived 
positively because of its contribution to students' motivation and enthusiasm (58\%), mathematics learning $(47 \%)$, and teamwork (39\%). However, it was seen as negative because it hinders organising and scheduling (53\%) and teamwork (50\%), and $44 \%$ of participants mentioned other negative issues, such as irrelevance to mathematics, an unfamiliar teaching style to teachers and students, and requiring resources.

Table 5. Survey A findings for positive and negative characteristics of PBL in mathematics

\begin{tabular}{|c|}
\hline \\
\hline $\begin{array}{l}\text { Motivation and enthusiasm } \\
\text { (incitement, eagerness, joy, an } \\
\text { suitable challenges) }\end{array}$ \\
\hline $\begin{array}{l}\text { Mathematics learning } \\
\text { (i.e., gaining knowledge, } \\
\text { understanding, and mastery) }\end{array}$ \\
\hline
\end{tabular}

Teamwork

(listening to everyone's voice, peer learning, cooperation, and participation of all)

Understanding of multidisciplinarity

Pleasant atmosphere

(good flow, positive spirit, and productive environment)

Connection between theory and practice (proximity of practicality, connection to everyday life, contextuality, usefulness, application)

Perseverance

(commitment and carefulness) Organising and scheduling (defining the subject and planning time resource)

\section{Others}

(data processing and analysis, sense of success, versatile methods,

$\begin{array}{cc}f & \% \\ 37 & 57.8\end{array}$

Negative Characteristics

f \%

$\begin{array}{lll}\text { Challenges regarding motivation } & 11 & 17.2\end{array}$

(lack of motivation, desperation

and frustration, questioning, and nonchalance)

$30 \quad 46.9$ Problems with mathematics

$14 \quad 21.9$

learning

(inappropriate level of difficulty, not promoting learning,

knowledge gap, and cannot learn

from others' projects)

$2539.1 \quad$ Problems with teamwork

(problematic workload contribution [free riders], teamwork problems, only working with friends, and competition)

$12 \quad 18.8$ Problems with the given exercise

$11 \quad 17.2$

(confusion, insufficient

guidance/instruction, and

disorganized entity)

$11 \quad 17.2$ Classroom chaos

(children just having fun or not paying attention, noise, and misuse of mobile phones)

$10 \quad 15.6$ $-$

$6 \quad 9.4 \quad$ Lack of concentration

$\begin{array}{lllll}4 & 6.3 & \text { Problems with organising and } & 34 & 53.1\end{array}$ scheduling (waste of time, lack of time, problematic schedule from teacher's or student's perspective, required planning time, not going as planned, and incomplete projects)

$16 \quad 25.0 \quad$ Others

(irrelevance to mathematics, information copying, unfamiliar 
student-centred learning, differentiation, communication, project outputs, and rewarding for teacher) teaching style to teachers and students, unconvincing method, inadequate working skills, lack of creativity, lack of resources, and dullness)

Non-responses

$0 \quad 0.0 \quad$ Non-responses

$4 \quad 6.3$

Note: Eight of the most mentioned responses are presented separately in the table. The remaining responses are grouped together and presented as others in the table. Positive and negative characteristics related to the same issue were positioned in the same row to facilitate comparison. The percentage of each characteristic was calculated in relation to the number of participants $(n=64)$.

We also examined (positive) PBL characteristics, which were those that the participants of Survey B ( $n$ = 193) strongly agreed were the most important (Item B2), as seen in Table 6. Nearly half of the participants considered the development of teamwork skills (45\%) as the most important, followed by growth of responsibility (41\%) and connection between theory and practice (39\%).

Table 6. Survey B characteristics that participants strongly agreed were the most important in PBL

\begin{tabular}{lll}
\hline \multicolumn{1}{c}{ Characteristics } & $f$ & \% \\
\hline Development of teamwork skills & 86 & 44.8 \\
Growth of responsibility & 78 & 40.6 \\
Connection between theory and practice & 75 & 39.1 \\
Development of data collection skills & 71 & 37.0 \\
Development of learning skills & 69 & 35.9 \\
Development of problem-solving skills & 66 & 34.4 \\
Learning of communication and career skills & 65 & 33.9
\end{tabular}

Note: $n=193$; non-respondents $=1$.

What the participants of both surveys regarded as important characteristics of PBL were somewhat diverse (see Tables 5 and 6). However, the development of teamwork skills and the connection between theory and practice were both deemed highly important characteristics of PBL.

The shared perspectives of participants of both surveys on PBL characteristics are consistent with the literature. The view on the connection between theory and practice corroborates that of Kokotsaki et al. (2016), Krajcik and Blumenfeld (2006), Larmer et al. (2015), and Thomas (2000), while the perspective on the development of teamwork skills substantiates that of Alozie et al. (2010) and Kokotsaki et al. (2016). In accordance with the results of Survey A, previous studies have demonstrated that PBL is a student-centred learning process (Kokotsaki et al., 2016; Krajcik \& Blumenfeld, 2006; Larmer et al., 2015; Thomas, 2000) and that it leads to project outputs (Alozie et al., 2010; Krajcik \& Blumenfeld, 2006; Larmer et al., 2015). Additionally, the development of problemsolving skills found in Survey B partly confirms the PBL characteristic proposed by Larmer et al. (2015). One unexpected finding was that inquiry-based and constructive investigation, as reported by Kokotsaki et al. (2016), Krajcik and Blumenfeld (2006), Larmer et al. (2015), and Thomas (2000), were not explicitly mentioned by any of the participants of this study.

Suitable application and situation regarding implementation of PBL.

Teachers' views regarding the applicability and implementation of PBL in mathematics in terms of suitable applications and situation can influence how they actually implement PBL in their mathematics classrooms. Therefore, we first examined what Survey A participants regarded as a suitable application for implementing PBL in mathematics (Item A3.1). Table 7 shows how the preand in-service teachers responded to five claims regarding the suitability of implementing PBL in 
mathematics. Overall, PBL was considered suitable for implementation in mathematics education. Only a small number of participants (12\% of pre-service and $4 \%$ of in-service teachers) thought that PBL was unsuitable for mathematics. In terms of suitable applications, a majority considered PBL to be suitable for revising mathematics content (95\% of pre-service and $100 \%$ of in-service teachers) and for learning new content ( $71 \%$ of pre-service and $91 \%$ of in-service teachers). Some participants (12\% of pre-service and $22 \%$ of in-service teachers) thought that PBL could be used only for learning less important things. However, most of the participants (78\% of pre-service and $87 \%$ of in-service teachers) thought that mathematics plays a less important role as a supportive tool in a project consisting of other study subjects. Overall, both groups of teachers shared a similar opinion on suitable applications for implementing PBL in mathematics. However, the in-service teachers were more open-minded than the pre-service teachers that PBL is suitable for using for any mathematics learning as long as that to-be-learnt content is not important.

Table 7. Survey A on teachers' opinions of suitable applications for implementing PBL in mathematics by type of teacher

\begin{tabular}{llccc}
\hline \multicolumn{1}{c}{ Claims } & \multicolumn{1}{c}{ Respondents } & $\begin{array}{c}\text { Agree } \\
f(\%)\end{array}$ & $\begin{array}{c}\text { Disagree } \\
f(\%)\end{array}$ & $\begin{array}{c}\text { Do not know } \\
f(\%)\end{array}$ \\
\hline PBL is NOT suitable for & Pre-service teachers & $5(12.2)$ & $35(85.4)$ & $1(2.4)$ \\
mathematics education. & In-service teachers & $1(4.3)$ & $21(91.3)$ & $1(4.3)$ \\
$\begin{array}{l}\text { PBL is suitable for revising } \\
\text { mathematics contents. }\end{array}$ & Pre-service teachers & $39(95.1)$ & $1(2.4)$ & $1(2.4)$ \\
PBL is suitable for learning & In-service teachers & $23(100)$ & $0(0.0)$ & $0(0.0)$ \\
new content. & Pre-service teachers & $29(70.7)$ & $10(24.4)$ & $2(4.9)$ \\
$\begin{array}{l}\text { PBL can ONLY be used for } \\
\text { learning less important }\end{array}$ & In-service teachers & $21(91.3)$ & $2(8.7)$ & $0(0.0)$ \\
things. & In-service teachers & $5(12.2)$ & $34(82.9)$ & $2(4.9)$ \\
$\begin{array}{l}\text { Mathematics is a } \\
\text { supportive tool for }\end{array}$ & Pre-service teachers & $32(78.0)$ & $1(2.4)$ & $8(19.5)$ \\
projects in other study & In-service teachers & $20(87.0)$ & $1(4.3)$ & $2(8.7)$ \\
subjects. & & & & \\
\hline N & & & & \\
\hline
\end{tabular}

Note: $n=64 ;$ non-respondents $=0$.

Second, we investigated the participants' open responses, including a suitable situation for implementing PBL in mathematics and reasons for that choice of timing (Item A3.2). Table 8 presents their responses categorised into five themes of appropriate situations for PBL implementation. Three of the categories (i.e., for revision, for learning new content, and a supportive tool for projects in other study subjects) were the same as three of the claims provided in Item A3.1, while two new categories (i.e., at any time and for differentiation) derived from the coding of Item A3.2. About half of the participants $(52 \%)$ thought that PBL was suitable for revision, including for deepening students' knowledge of what has already been learned, for applying their knowledge, for recalling what was previously learned, or for providing the overall picture of the subject. About $30 \%$ felt that PBL could be used at any time, whereas about $16 \%$ viewed PBL as appropriate for learning new content. 
Table 8. Survey A on teachers' opinions regarding suitable situation for implementing PBL in mathematics

\begin{tabular}{|c|c|c|c|}
\hline Suitable Situation & $f$ & $\%$ & Sample Responses \\
\hline For revision & 33 & 51.6 & $\begin{array}{l}\text { 'Revision of what already learned: in my opinion, } \\
\text { foundation stuffs [study contents] have to be attained } \\
\text { first, so called in a traditional way, after that they can } \\
\text { be deepened in a project.' }\end{array}$ \\
\hline For learning new content & 10 & 15.6 & $\begin{array}{l}\text { 'In my opinion, it [PBL] is suitable for learning new } \\
\text { things because, in this context, it is important to } \\
\text { provide concrete examples as well as to link the topic } \\
\text { to the children's world of experience, which project } \\
\text { work can help accomplish' }\end{array}$ \\
\hline At any time & 19 & 29.7 & $\begin{array}{l}\text { 'With good planning, project work can be suitable for } \\
\text { any [learning] stage' }\end{array}$ \\
\hline $\begin{array}{l}\text { As a supportive tool for } \\
\text { projects in other study } \\
\text { subjects }\end{array}$ & 4 & 6.3 & $\begin{array}{l}\text { 'As a supportive tool in other study subjects, it [PBL] } \\
\text { provides a good opportunity to work on, among } \\
\text { other things, challenging mathematics in physics } \\
\text { projects' }\end{array}$ \\
\hline For differentiation & 1 & 1.6 & 'Why not for upward differentiation?' \\
\hline
\end{tabular}

Note: $n=64 ;$ non-respondents $=4$.

When comparing the participants' responses to Items A3.1 and A3.2, disagreement was found between their responses to both items in terms of the suitability of PBL for learning new content. Interestingly, for the Likert-type item, $71 \%$ of pre-service and $91 \%$ of in-service teachers agreed that PBL is suitable for learning new things (see Table 7), but only $16 \%$ of them were of the same view according to the open-ended item (see Table 8).

Support for and barriers to PBL implementation.

To explore how to support the implementation of PBL, we first examined Survey A participants' viewpoints on factors that support (Item A4.1) and hinder (Item A4.2) PBL in mathematics. Figure 3 shows that the participants considered that the resources provided by the school, the teacher's professional skills and motivation, available project ideas, students' competence prior to the project, interaction among students and between the teacher and students, collegial support, flexibility of schedule, and curriculum can either support or hinder the implementation of PBL. For example, good project ideas can facilitate project work, whereas a lack of project ideas can make it difficult to start a project. The pre- and in-service teachers had varying views regarding the factors that support PBL. The pre-service teachers considered good project ideas (29\%) followed by good student competence prior to the project $(27 \%)$ as factors that facilitate $\mathrm{PBL}$, while a majority of the in-service teachers regarded a lack of resources provided by the school $(61 \%)$ followed by collegial support $(48 \%)$ as facilitators. However, both groups shared a similar opinion on the three most frequently cited hindrances to PBL: inflexible schedule ( $42 \%$ and $48 \%$ of pre- and in-service teachers, respectively), a lack of teachers' professional skills and motivation $(29 \%$ and $22 \%$ of pre- and in-service teachers, respectively), and a lack of resources provided by the school (27\% and $48 \%$ of pre- and in-service teachers, respectively). Nevertheless, it was difficult to investigate the similarities and differences between the pre- and in-service teachers' responses due to the small number of participants in each group. 


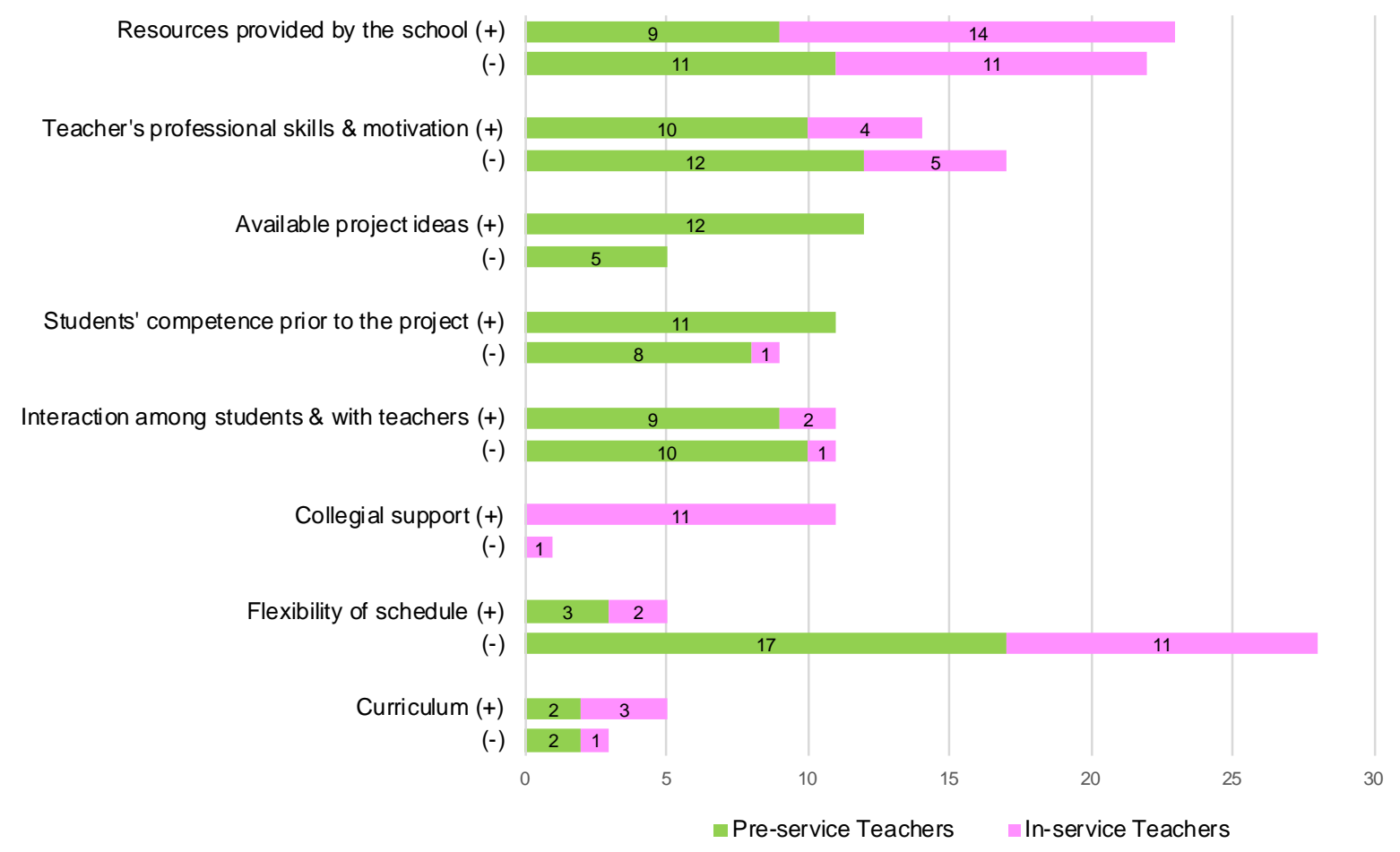

Figure 3. Survey A response frequency for teachers' opinions regarding what supports (+) or hinders (-) PBL in mathematics by types of teachers

Note: In-service teachers: $n=23$; non-respondents $=0$. Pre-service teachers: $n=41$; $(+)$ nonrespondents $=4$ and $(-)$ non-respondents $=3$.

Second, we investigated whether the participants in Survey B felt that their schools provided enough time and material resources to the integrative learning modules through PBL (Item B4.1). Altogether, $40 \%$ of the participants $(n=193)$ felt that the resources provided by their schools were sufficient (strongly agreed or agreed), and only $26 \%$ of them did not feel that resources were sufficient (strongly disagreed or disagreed).

Finally, we examined what kind of support the participants needed in order to implement PBL in mathematics (Item A4.3) and in mathematics and sciences (Item B4.2). The opinions were mostly consistent across both surveys. The participants of both surveys expressed the need for different types of support (see Figure 4), the most important of which included ready-made project instructions, ideas, tips, and examples (67\% in Survey A and $29 \%$ in Survey B). Some of the participants $(22 \%$ in Survey A and $12 \%$ in Survey B) stated that they would like to receive advice from experienced teachers about what works and what does not. Moreover, $17 \%$ of participants in Survey A and $12 \%$ in Survey B wanted training and guidance on basic PBL issues. Nevertheless, there were some divergent opinions between the two surveys. About $4 \%$ of participants in Survey B stated that they would like to receive guidance on ICT, whereas no one from Survey A mentioned this. Further, $6 \%$ of Survey B participants explicitly stated that they did not need any support. 
I do not need any support Ready-made project instructions, ideas, tips, and examples Advice from experienced teachers Training and guidance on basic PBL issues
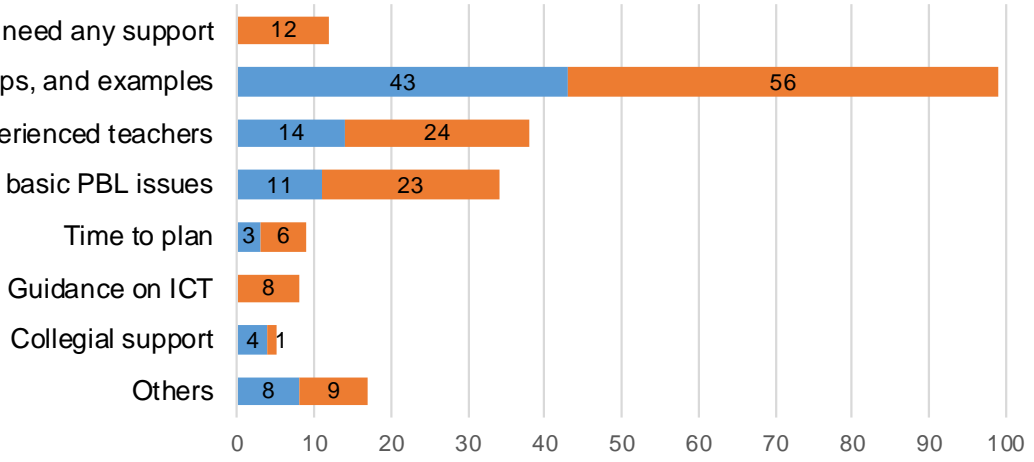

- Survey A - Survey B

Figure 4. Response frequency on support needed for implementing PBL

in mathematics and science by survey

Note: For Survey A, pre-service teachers: $n=41$; non-respondents $=5$. In-service teachers: $n=23$, nonrespondents $=2$. For Survey B, $n=193$; non-respondents $=60$. The remaining responses, including assessment, more teaching resources, courage, space, the utilisation of the learning environment, and outside school partnership were grouped together and presented as others. Some participants listed more than one type of needed support. Thus, these responses were also included in the data.

In accordance with the literature (e.g., Habók \& Nagy, 2016; Kokatsaki et al., 2016; Tal et al., 2006), the results of Survey A demonstrate that teachers' skills in relation to PBL implementation, good interaction among students, sufficient support from the school and colleagues, and the availability of project ideas are believed to support PBL implementation. Various barriers to the implementation of PBL were found, such as a lack of resources, inadequate teacher competence, and inadequate student knowledge and skills, thereby confirming previous research (e.g., Aksela \& Haatainen, 2019; Mentzer et al., 2017). Interestingly, teachers' motivations, which in this study were considered crucial for the success of PBL implementation, were not noted in the PBL literature. The findings regarding teachers' needs for support in implementing PBL in mathematics and science substantiate previous studies, for example, in terms of professional development; networking with teachers who have experience in PBL implementation (Kokatsaki et al., 2016); and ready-made project instructions, ideas, tips, and examples (Tal et al., 2006).

\section{Conclusions}

This study contributes to a better understanding of teachers' perspectives on PBL in mathematics and science. It identifies teachers' views of PBL objectives and characteristics, the suitable application and situation of implementing PBL, and support for and barriers to PBL implementation. The development of students' knowledge and understanding of mathematics and science as well as their 21st century skills were considered to be important PBL objectives. Additionally, the development of teamwork skills and the connection between theory and practice were regarded as key characteristics of PBL. PBL was seen as suitable for both revising and learning new mathematics content.

Numerous teachers in Survey A felt that the objective of PBL only concerns mathematics learning, whereas the Finnish National Core Curriculum for Basic Education 2014 (EDUFI, 2016a) requires the inclusion of multidisciplinary learning modules for all grade levels. Conversely, in Survey B, multidisciplinarity was regarded as the most important objective of PBL, while the development of mathematics and science played a minor role. In the future, the role of multidisciplinarity and the development of specific study subjects should be equally emphasised as important PBL objectives in mathematics and science. 
The findings identified somewhat inadequate resources and support for the implementation of PBL. Thus, the forms of support provided - particularly ready-made project instructions, ideas, tips, and examples; advice from experienced teachers; and training and guidance on basic PBL issues - would assist teachers in implementing PBL. Moreover, support from the school, for example, in the form of more time for planning and implementing a project, would enhance the success of PBL implementation. The findings of this study may also be useful in informing teachers' professional development of PBL.

Limitations and future studies.

Our work clearly has some limitations. The data collected only apply to the Finnish educational context. The number of participants in Survey A was relatively small, especially when the data were divided into pre- and in-service teachers' responses. Moreover, all of the pre-service teachers who participated were recruited from two different courses at the same university. The in-service teachers came from the continuing education course on PBL. Thus, it is likely that they were already interested in PBL. This might have influenced their survey responses. Although two authors coded the principles and resolved doubtful circumstances by reaching a joint decision, the data were mainly coded by one author. Additionally, the questionnaire only provided overviews of the teachers' perspectives. Despite these limitations, we believe that our research provides fruitful information on teachers' perspectives on PBL in mathematics and science.

A larger number of survey participants as well as randomised controlled trials are needed in future studies. Double coding by an independent person would increase the reliability of the data coding. Qualitative data collection methods, such as interviews and observations, could provide a deeper understanding of teachers' views on PBL. Additionally, while this research has identified teachers' perspectives on PBL, it would also be interesting to consider students' perspectives on PBL and their achievements in relation to the learning objectives.

\section{Acknowledgements}

This paper is part of two development projects: Project-Based Learning in Mathematics and Communitybased and Research-based Learning Environments in Teacher Education in the LUMA Ecosystem (CRLETELE), which are funded by the Finnish Ministry of Education and Culture. The authors would like to acknowledge the contributions of CRLETELE's working and steering group: Maija Aksela, Outi Haatainen, and Topias Ikävalko of the University of Helsinki; Pekka Hirvonen of the University of Eastern Finland; and Anna-Leena Kähkönen and Jan Lundell of the University of Jyväskylä. The authors are also grateful for the cooperation of LUMA Centre Finland.

\section{References}

Aksela, M. K. and Haatainen, O. M., (2019). Project-based learning (PBL) in practise: Active teachers' views of its advantages and challenges. Proceedings of the 5th International STEM in Education conference: Integrated Education for the Real World, 9-16.

Alozie, N., Eklund, J., Rogat, A. and Krajcik, J., (2010). Genetics in the 21st century: The benefits \& challenges of incorporating a project-based genetics unit in biology classrooms. The American biology Teacher, 72(4), 225-230.

Blumenfeld, P. C., Soloway, E., Marx, R. W., Krajcik, J. S., Guzdial, M. and Palincsar, A., (1991). Motivating project-based learning: Sustaining the doing, supporting the learning. Educational Psychologist, 26(3/4), 369-398. https://doi.org/10.1207/s15326985ep2603\&4_8

Campbell, S.A., (2012). The phenomenological study of ESL students in a project-based learning environment. International Journal of Interdisciplinary Social Sciences, 6(11), 139-152.

Capraro, R. M. and Slough, W. S., (2008). Why PBL? Why STEM? Why now? An introduction to STEM project-based learning: An integrated science, technology, engineering, and mathematics (STEM) approach. In R. M. Capraro, M. M. Capraro and J. R. Morgan (Eds.), STEM Project-based learning: An integrated science, technology, engineering, and mathematics (STEM) approach (pp. 1-6). Rotterdam, the Netherlands: Sense Publishers.

Common Core State Standards Initiative, (n.d.). Standards for mathematical practice. http://www.corestandards.org/Math/Practice/, (accessed June 2019) 
Erdogan, N. and Bozeman, T. D., (2015). Models of project-based learning for the 21st century. In A. Sahin (Ed.), A practice-based model of STEM teaching (pp. 31-42). Rotterdam, the Netherlands: Sense Publishers.

Finnish National Agency for Education (EDUFI)., (2016a). National core curriculum for basic education 2014 (Publications 2016:5). Helsinki, Finland.

EDUFI., (2016b). National core curriculum for general upper secondary schools 2015 (Publications 2016:8). Helsinki, Finland.

Habók, A. and Nagy, J., (2016). In-service teachers' perceptions of project-based learning. SpringerPlus, 5(1), 1-14. https://doi.org/10.1186/s40064-016-1725-4

Han, S., Yalvac, B., Capraro, M. M. and Capraro, R. M., (2015). In-service teachers' implementation and understanding of STEM project based learning. Eurasia Journal of Mathematics, Science and Technology Education, 11(1), 63-76.

Joutsenlahti, J., (2005). Lukiolaisen tehtäväorientoituneen matemaattisen ajattelun piirteitä - 1990 luvun pitkän matematiikan opiskelijoiden matemaattisen osaamisen ja uskomusten ilmentämänä [Characteristics of task-oriented mathematical thinking among students in upper secondary school] (Doctoral dissertation). Tampere University, Finland. http://urn.fi/urn:isbn:951-44-6204-1, (accessed June 2019)

Kay, K. and Greenhill, V., (2011). Twenty-first century students need 21st century skills. In W. Guofang and D. M. Gut (Eds.), Bringing schools into the 21st century (pp. 41-66). New York: Springer.

Kilpatrick, J., Swafford, J. and Findell, B., (2001). Adding it up: Helping children learn mathematics. Washington DC: National Academies Press.

Kokotsaki, D., Menzies, V. and Wiggins, A., (2016). Project-based learning: A review of the literature. Improving Schools, 19(3), 267-277.

Krajcik, J. S. and Blumenfeld, P. C., (2006). Project-based learning. In R. K. Sawyer (Ed.), Cambridge handbook of the learning sciences (pp. 317-405). West Nyack, NY: Cambridge University Press.

Kumpulainen, T. (Ed.), (2017). Opettajat ja rehtorit Suomessa 2016 [Teachers and headmasters in Finland 2016] (Reports 2017:2). Helsinki, Finland: EDUFI.

Larmer, J., Mergendoller, J. and Boss, S., (2015). Setting the standard for project based learning: A proven approach to rigorous classroom instruction. Alexandria, VA: ASCD.

Markham, T., Larmer, J. and Ravitz, J., (2006). Project based learning handbook (2nd ed.). Novato, CA: Buck Institute for Education.

Marx, R., W., Blumenfeld, P. C., Krajcik, J. S. and Soloway, E., (1997). Enacting project-based science. The Elementary School Journal, 97(4), 341-358.

Mentzer, G. A., Czerniak, C., M. and Brooks, L., (2017). An examination of teacher understanding of project based science as a result of participating in an extended professional development program: Implications for implementation. Teacher Extended PBS PD, 117(1/2), 76-86.

Moschkovich, J., (2015). A sociocultural approach to academic literacy in mathematics for adolescent English learners: Integrating mathematical proficiency, practices, and discourse. In D. Molle, E. Sato, T. Boals and C. Hedgspeth (Eds.), Multilingual learners and academic literacies: Sociocultural contexts of literacy development in adolescents (pp. 75-104). New York, NY: Routledge.

National Research Council, (2012). A framework for K-12 science education: Practices, crosscutting concepts, and core ideas. Washington, DC: National Academies Press.

Organisation for Economic Co-Operation and Development (OECD), (2019). PISA 2018 assessment and analytical framework. Paris: OECD Publishing. https://doi.org/10.1787/f30da688-en, (accessed June 2019).

Ozaki, T., Hirose, H., Ichikawa, H., Yamamoto, Y. and Amagasa, M., (2017). Verification of class improvement of project-based learning in appraisal method with fuzziness. Proceedings of the ICETC 2017, 104-108.

Partnership for 21st Century Skills (P21), (2007). Beyond the three Rs: Voter attitudes toward 21st century skills. Tucson, AZ: Author. http://www.p21.org/storage/documents/P21_pollreport_singlepg.pdf, (accessed June 2019)

Tal, T., Krajcik, J., and Blumenfeld, P., (2006) Urban schools' teachers enacting project-based science. The Journal of Research in Science Teaching, 43(7), 722-745.

Thomas, J. W., (2000). A review of research on project-based learning. San Raael, CA: Autodesk Foundation. http://www.bie.org/object/document/a_review_of_research_on_project_based_learning, (accessed June 2019)

Viro, E. and Joutsenlahti, J., (2018). Projektityöskentelyn kehittäminen yläkoulun matematiikan opetuksessa [The development of project work in lower secondary school's mathematics education]. FMSERA Journal, 2(1), 90-99.

Viro, E., Joutsenlahti, J. and Eriksson, S-L., (2016). Projektityöskentely matematiikan opiskelussa yläkoululaisten ja heidän opettajiensa kokeman [Project work in mathematics education from the perspective of secondary pupils and their teachers]. FMSERA Journal, 1(1), 121-131.

World Economic Forum (WEF). (2018). The future of jobs report 2018 (Insight Report). http://www3.weforum.org/docs/WEF_Future_of_Jobs_2018.pdf, (accessed June 2019) 